v.11, n.6

Vitória-ES, Nov.-Dez. 2014

p. 1 - 21 ISSN 1808-2386 DOI: http://dx.doi.org/10.15728/bbr.2014.11.6.1

\title{
Securitization, Credit Rating and Issuers' Characteristics
}

\author{
Mauricio Palmada Fernandes ${ }^{\dagger}$ \\ Orsa International Paper \\ Hsia Hua Sheng ${ }^{\Omega}$ \\ Fundação Getúlio Vargas - EAESP/FGV \\ Universidade Federal de São Paulo - EPPEN/UNIFESP \\ Mayra Ivanoff Lora ${ }^{\#}$ \\ Fundação Getúlio Vargas - EESP/FGV
}

\begin{abstract}
Given the growth of securitization through Credit Receivables Investment Funds (Fundos de Investimento em Direitos Creditórios - FIDCs) in Brazil in recent years, this work aims to investigate empirically the relationship between securitization and credit rating in the Brazilian market. All issues of FIDCs held by banks and registered in the CVM from 2005 to July 2010 were analyzed. The two hypotheses discussed by Gorton and Souleles (2005) were confirmed to Brazilian financial institutions. There is evidence of an implied contract between the transferor companies and investors in securitizations made via FIDCs. Companies with higher credit risk, worst ratings, tend to securitize more. However no relationship was found between securitization and asset value, amount of loans or capital ratio.
\end{abstract}

Keywords: Securitization. Rating. Implicit contract. FIDCs. Spread.

Received on July 24, 2012; reviewed on January 23, 2014; accepted on March 24, 2010; disclosed on November 27, 2014

*Author for correspondence:

${ }^{\prime}$. Masters Degree from the Escola de Economia de Sao Paulo of Fundação Getulio Vargas.

Institution: CFO at International Paper Orsa

Address: Rua Princesa Isabel, São Paulo - SP - Brazil

E-mail: mauriciopfernandes@gmail.com Telephone: (11) 994562429

\footnotetext{
${ }^{\Omega}$ Doctorate from Fundação Getulio Vargas (FGV-EAESP)

Institution: Professor of Finance at Escola de Administração de Empresas de São Paulo of Fundação Getulio Vargas (FGV-EAESP) and Professor of Finance of Escola Paulista de Política, Economia, e Negócios at Universidade Federal de São Paulo (UNIFESP - EPPEN). Address: Rua Itapeva, São Paulo - SP - Brazil E-mail: hsia.sheng@fgv.br

Telephone: (011) 3799-7769
}

\footnotetext{
¥ Doctorate from Instituto de Matemática e Estatística of Universidade de São Paulo Institution: Professor of Statistics and Mathematics at Escola de Economia de São Paulo of Fundação Getúlio Vargas (FGV/EESP)

Address: Rua Itapeva, São Paulo SP - Brazil

E-mail: mayra.lora@fgv.br Telephone: (11 ) 37993362
} 


\section{INTRODUCTION}

Financing through securitization of receivables in Brazil has grown significantly

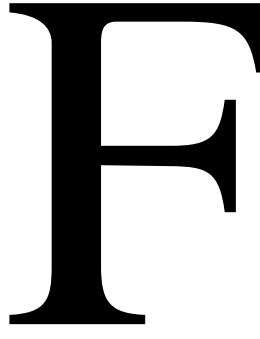

in recent years, especially after the regulation of Credit Receivables Investment Funds (FIDCs), in 2001, due to its tax advantages. If considered the value of shares issued per year, taking into account the emissions registered, exempted from registration and restricted effort (ICVM 476), available from the Brazilian Association of Financial and Capital Markets (Associação Brasileira das Entidades dos Mercados Financeiro e de Capitais - ANBIMA) web sites and the Brazilian Securities Commission (Comissão de Valores Mobiliários - CVM), there has been a substantial increase, from R $\$ 200$ million in 2002 to $\mathrm{R} \$ 10$ billion in 2009 , reaching a maximum, in 2008, of $\mathrm{R} \$ 13$ billion.

Securitization in Brazil, structured through FIDCs, differs from the more frequent form in the United States, which is used to create Special Purpose Vehicles (SPVs), which issue asset-backed securities in the market to finance the acquired assets. Although differing in legal form, since the figure of the Trust does not exist in Brazil, such structures have many features in common, notably the possibility of off-balance sheet financing, credit enhancement mechanisms and tax neutrality.

The growth of securitization in Brazil and the recent problems experienced with the emissions from some local banks have made the Central Bank of Brazil to increase control over these structures through the resolution 3533 and the establishment of the Center for Credit Assignment (Central de Cessão de Crédito).

Gorton and Souleles (2005) and Thomas and Wang (2009) point to the reducing of the costs of bankruptcy as one of the main benefits of securitization structures, given their own structural characteristics. This factor can be directly associated with the reduction of funding costs quoted by Fabozzi and Kothari (2007). Another advantage would be the possibility of earnings management, as analyzes Karaoglu (2005). The use of off-balance sheet structures as a tool to optimize the capital structure is also discussed in Leland (2007) and Ayotte and Gaon (2005). Fishman and Kendall (1996) also highlight the increase in liquidity for investors and forms of funding as other possible benefits.

Another issue on securitization addressed by the academic studies is the existence or not of an implied contract between the final investor and the originator of the securitized assets. Such an approach proves to be relevant, since this contract contradicts the need to show a true sale, so that such structures are classified as off-balance sheet. Gorton and Souleles (2005) 
conclude that, to be a long-term equilibrium in securitization structures, there must be an implicit non-formal contract between the originator and the investors. Gorton and Penacchi (1989) and Higgins and Mason (2003) have already evaluated this hypothesis for the sale of assets by banks (loan sales). The discussion on the maintenance or not of the risk of the securitized assets and treated as off-balance sheet in the origination companies has gained more relevance, as to the Financial Accounting Standards Board (FASB) to disclose the Interpretation No. 46 (FIN 46), increasing the control on certain structures.

Therefore, the aim of this work is to analyze the characteristics of securitization in Brazil testing two hypotheses discussed by Gorton and Souleles (2005) for the Brazilian market: if there is evidence of an implied contract between the transferor companies and investors in securitizations made via FIDCs; and if companies that offer higher credit risk securitize more. The contribution of this paper is to analyze the economic impacts of securitization in the Brazilian market and discuss how the difference in operation between the Brazilian and American securitization markets impacts in the structuring of these transactions.

\section{THEORETICAL REFERENCE}

In recent years, the literature on securitization has been well developed, especially in the American market, in which many articles have been published discussing these structures under different viewpoints.

\subsection{BENEFITS OF THE SECURITIZATION STRUCTURES}

Fabozzi and Roever (2003) define as main sources of value of securitization structures the lower funding costs, earnings management and the possibility of improvement of financial indicators through off-balance sheet financing. The lower funding costs derived from the securitization structure itself, since the SPV may have a better credit rating than the originator. The possibility of earnings management comes from the American accounting standards, enabling the use of a portfolio of receivables or assets to accelerate gains in reports to shareholders. Most of these benefits is recurrent in the literature, cited in studies such as Fishman and Kendall (1996).

Besides the already highlighted benefits, Fabozzi and Kothari (2007) added the possibility of risk management, since the originating company ceases to possess the risks related to securitized assets, and also the removal of the financial intermediary, as that securitization allows access to the capital market without the intermediation of financial 
institutions. Karaoglu (2005) presents evidence that the gains from transfers of loans are used by banks to manage regulatory capital and the reported profits.

Aligned to the analysis of Fabozzi and Roever (2003), Gorton and Souleles (2005) highlight how one of the main advantages of the securitization structures the reduction of bankruptcy risk, because such structures are shaped so as to have remote chances of bankruptcy. This fact would allow the originator to reduce their funding costs, since there would be no risk premium for bankruptcy. The reduction in financing costs is also mentioned in the works of Thomas and Wang (2009), Mills and Newberry (2005) and Lemmon, Liu and Mao (2010). Ayotte and Gaon (2005) demonstrate that the protection generated by securitization structures in bankruptcy is valued by the market and the prime factor in the pricing of such instruments.

The discussion about the possible benefits of securitization in the capital structure of the transferor companies have also been studied in recent articles. Skarabot (2001) assumes that, for certain relations of variance and covariance between assets, securitization can optimize the value of the company. Leland (2007) considers that the separation of operating assets in different institutions allows each institution to have its optimal capital structure and that separating the limitations of liability may lead to higher leverage. Moreover, such structures can bring even more significant benefits when there is a big difference in volatility between the cash flows and the cost of bankruptcy of assets. To Ayotte and Gaon (2005), securitization of assets that can be replenished prevents the continued inefficiency in bankruptcy. However, in the case of necessary assets (e.g. fixed assets, intangibles, inventories), other instruments such as leasing may be the best sources of funding.

Finally, Karaoglu (2005), Korgaonkar and Nini (2010) and Lemmon, Liu and Mao (2010) argue that problems such as information asymmetry, asset substitution and underinvestment (Myers, 1977) faced by companies with high leverage may be minimized through the securitization of assets, since this can be thought of as an extreme form of secured debt.

\subsection{CHARACTERISTICS OF FIRMS THAT SECURITIZE}

In view of the benefits mentioned in the literature, such as reducing financing costs and the possibility of improvement of financial indicators, it is logical to presume that firms with higher credit risk (worst rating) or with greater incentive to improve their balance sheets should use more securitization structures. According to Korgaonkar and Nini (2010), the benefits of securitization being apparently linked to the segregation of assets of a possible risk 
of bankruptcy of the transferor company, as the risk of bankruptcy of the transferor company grows, so do the benefits of securitization.

This argument also appears in the model of Gorton and Souleles (2005), in which the gain from securitization increases with the risk of bankruptcy of the transferor company. Through empirical analysis, the authors find evidence that firms with higher bankruptcy risks, worst ratings, securitize more, confirming their hypothesis.

Mills and Newberry (2005) found evidence that companies with poor credit ratings, high leverage and a large proportion of debt to be negotiated in the short-term use more securitization structures. This finding suggests that the financial reports of companies can motivate the use of off-balance sheet financing with the intention of reducing leverage ratios and lower credit risk. Moreover, they suggest that firms respond to financial constraints using more off-balance sheet financing.

Korgaonkar and Nini (2010) in their study of non-financial companies in 2006, conclude that those that used securitization had relatively high credit risk, but were not in financial constraints. For the authors, these results are related to the costs and benefits of offbalance sheet financing. The benefits come from a reduction in bankruptcy costs and, therefore, higher according to the risk of bankruptcy. These companies, despite having higher credit risk (worst rating), were also larger, had low bank indebtedness, were a little older than the average and had a low market-to-book ratio. These characteristics, according to the authors, are from companies that have less chance of having financial constraints. The low debt is explained by the fact that the on-balance financing of the companies with high credit risk generally occurs through debt with guarantee contracts that prevent asset securitization. The authors suggest that companies need to be large and have plenty of receivables to support the creation of an SPV.

Differently from conventional view that companies without access to capital markets would securitize more, Lemmon, Liu and Mao (2010) argue that, as the SPVs issue debt in the market, companies that already have access to such markets should have more access to securitization . Defining the existence of rating as a proxy for access to capital markets, they empirically found that industries that used securitization had higher probability of having a credit rating when compared to other industries. Aligned with Korgaonkar and Nini (2010), they have assessed that such companies were bigger and greater percentage of accounts receivable, linking the size to the capability of absorbing the costs of structuring a SPV. They also found that the probability of securitization increases when increases the difference 
between the risks of securitized and non-securitized assets, and that the rating of the transferor company worse after securitization, since assets with lower risk are securitized. Finally, it was also noted that the use of securitization decreases when it has to be consolidated in the balance sheet, suggesting that companies are concerned about the financial reporting when determining the use of securitization.

\subsection{IMPLIED CONTRACT AND RISK TRANSFER}

Another feature very present in the literature on securitization is the relationship between the investor and the originator of the assets. This discussion is relevant because, for accounting purposes for a structure of securitization to be considered off-balance sheet, the assignment of assets should be done through a true sale, that is, the transferor company must not retain any control over the assets ceded (GORTON; SOULELES, 2005). However the same authors argue in their theoretical model that the balance of securitization structures over the long term is only possible if there is an implicit non formal contract between investors and the transferor company of the receivables. Through this implicit contract, the transferor companies would agree to subsidize or rescue the SPV if that come through performance issues. This contract or implicit guarantee also appear as a way to mitigate the problem of adverse selection of assets, since the transferor company, having more information than the investors, is responsible for selecting the assets to be sold to the SPV. In the case of rotating assets that must be renewed over time, this effect would be even more relevant.

Such implied contract could not be formalized, because it contradicts the accounting rules and the need for a true sale for the financing through off-balance sheet securitization to be considered. However the possible existence of such contract has been perceived by the regulators, the rating agencies and by researchers, it being defined by the regulators of the banking market as a provision of credit support beyond contractual obligations (GORTON; SOULELES, 2005).

Gorton and Pennacchi (1989) find empirical support for the hypothesis of implicit guarantees. Since the sale of loans must be made without recourse to be characterized as offbalance sheet, for authors such structure only makes sense for the buyer if there is an implicit guarantee by the bank, given the asymmetry of information between buyers of loans and the banks that issues them. Thus, the premium paid on the sale of these loans should reflect the risk of default of the seller's bank.

Higgins and Mason (2003) argue that information asymmetry of bank assets makes them fundamentally illiquid and thus the securitization appears as a way to sell such assets 
and increase liquidity. Thus, put the existence of an implied contract as required in securitization structures, mainly in structures involving revolving credit like credit cards. Such a contract would also be encouraged because banks have an interest in maintaining their reputation, since its loss would result in decreased liquidity, increased cost of interest rate and greater oversight by regulators. Through an empirical study, they show that banks have honoured such implicit contract when necessary had an increase in their actions in the long and short term. Higgins, Mason and Mordel (2009) analyze empirical evidence that investors in transferor companies see securitization more as a financing rather than a sale of assets, one reason being the low risk transfer of assets.

The association of implicit contracts with asymmetric information and adverse selection also appears in the study of Chen, Liu and Ryan (2008) on the retention of the risks of securitization by the transferor. As in Higgins and Mason (2003), the implied warranties would be an issue only for securitizations involving revolving credit and without fixed maturity, because in these cases there is a future uncertainty. Maintaining the reputation by the transferor also appears as a supporter for the existence of an implied contract, since it could guarantee future securitizations. The authors emphasize four forms of intervention by the transferor if the securitized assets are experiencing performance issues: contributions to assets granted below market price, purchase of assets by the SPV with a higher price than the market's, exchange of low quality assets for assets of better quality and offer enhanced credit beyond the contractual.

In the model developed by Gorton and Souleles (2005), the implicit contract appears as crucial to the balance of securitization structures in long-term. In the same line as Chen, Liu and Ryan (2008), such contract would exist because banks have an interest in maintaining their reputation and continue using securitization structures in the future. Analyzing securitizations of receivables from credit cards by banks, they conclude that the credit rating of the transferor bank of the receivables influences the spread charged on the securitization of these assets. For the authors, this relationship highlights the existence of implicit contracts, since the securitization structures, because they have possibilities of bankruptcy remote, should not depend on the rating of the transferor companies.

The hypothesis of contract or implicit guarantees is contradicted by Lemmon, Liu and Mao (2010) that found evidence that the studied industries, the SPVs appear to have remote chances of bankruptcy and are independent of the characteristics of the transferor. In line with this conclusion, Fabozzi and Kothari (2007) point out that the credit rating of the 
securitization structures does not depend on the financial condition of the sellers, but the assets designated for securitization and credit enhancements instituted.

\subsection{STUDIES OF SECURITIZATION IN BRAZIL}

Not much has been discussed in the literature on securitization in Brazil. Probably part of it is due to the recent growth in the volume of securitization in the country after the regulation of FIDCs in 2001, and the difficulty of obtaining data. Of published studies, one can cite Catão et al. (2009), that analyzed the impact of securitization through FIDCs levels of leverage, in credit quality and liquidity of the transferor banks. Analyzing a sample of 10 banks with FIDCs 12 public offerings concluded that, in $90 \%$ of the studied banks, there were significant relationships between securitization operations and indicators analyzed. Pinheiro and Savoia (2009) evaluated the risks and returns of investments in senior and subordinated quotas in FIDCs in Brazil. Conclude that, for investors in senior quotas, it is unlikely a lower return than indicated by the fund, and, for investors in subordinated quotas, it is low the risk of retourn below the Certificado de Depósito Interbancário - CDI (Interbank Deposit Certificate).

\section{SECURITIZATION STRUCTURES OF RECEIVABLES IN BRAZIL}

The securitization of receivables in Brazil began in the 90s, through transactions with the use of Special Purpose Entities (SPEs) and the issuance of debentures backed by receivables. However, primarily due to the tax advantage of FIDCs on SPEs, securitization has gained momentum in the Brazilian market after regulation of FIDCs in 2001. In structuring a FDIC, a company cedes definitively the receivables to the fund, which will issue shares to be acquired by qualified investors as defined by CVM.

According to Brazilian accounting standards, for proper accounting for securitization transactions on the balance sheets of the transferor companies, one should take into account primarily the economic essence of the transaction, not just its legal form (GELBCKE; IUDÍCIBUS; MARTINS, 2009). Thus, it should be considered the following points: a) if the control of the assigned receivables remains with the company; b) if the company retains any right, liability or risk for the assigned receivables; c) if the company provides guarantees to investors of FDIC.

If any of the above features are present, one can show a financing transaction that should be accounted for as such. If none of these characteristics is present, the accounting of assigned receivables will be similar to a sale of assets (GELBCKE; IUDÍCIBUS; MARTINS, 2009). 
This concept was introduced in the financial market by the Resolution 3533, issued by the Central Bank of Brazil in 2008. This resolution follows the accounting principle of International Financial Reporting Standards (IFRS) and allows the low of a financial asset only when there is substantial transfer of risks and benefits, that is, when the selling institution has significantly reduced its exposure to the variation in the present value of future cash flow of the financial asset involved in the transaction. Expected to come into force in 2009, the Resolution 3533 was implemented only in 2011. Before implementation, there was little stiffness in the criteria used by banks to consider assets as off-balance sheet.

Recently, the assignment of receivables for FIDCs was at the center of many of the problems that were found in banks as Panamericano, Morada and Cruzeiro do Sul. In these cases, the presence of fictitious loans, the duplicate sale of credits, the sale of shares of funds to companies of the same group, among others, led the Central Bank to increase the rigor of supervision. Only in 2011, in addition to Resolution 3533, the Central Bank implemented the Center for Credit Assignment and a monthly breakdown of off-balance operations was required.

\section{DEFINITION OF ASSUMPTIONS}

Relying on the article of Gorton and Souleles (2005), this work is meant to test for the Brazilian market two hypotheses that have been tested by the authors in the American market.

The first hypothesis (H1) is based on argument that the ability of a company to finance itself through securitization depends on an implicit contract between companies and investors. As the transferors will only be able to redeem the FDIC if they continue to exist, if there is the risk of bankruptcy and, therefore, not fulfill the implicit agreement, the investors will not buy quotas of such fund. Under these conditions, this article tests the hypothesis that investors take into account the credit risk (rating) of the transferor when they do the pricings for the funds quotas.

The second hypothesis $(\mathrm{H} 2)$ is derived from the very source of the value of securitization transactions, namely, the reduction of bankruptcy costs. The higher bankruptcy costs, the greater would be the benefits of securitization and, therefore, the transferor at higher risk of bankruptcy should securitize more.

This paper aims, through empirical testing, to determine whether such assumptions considered relevant to the American market can also be found in securitization transactions in 
Brazil, corroborating the theoretical foundation exposed. The analyses take into account the structures of FIDCs and the adaptation of some explanatory variables to this environment.

\section{DESCRIPTION OF THE DATABASE}

For the scope of this study were analyzed all issues of FIDCs registered at CVM from 2005 to July 2010. This period was defined based on the availability of information on the releases of funds, since the data for the funds and for emissions prior to 2005 are scarce and inaccurate. Only from 2005 the regulatory authority has made available more widely the information on their site. Furthermore, there is no information at CVM about funds that have already been closed, making it more difficult to obtain information.

Analyzing the issues of FIDCs from January 2005 to July 2010, it was reached the number of records of 282 issues, some of which represent more than one class of quotas, or more than one series. For analyzing these issues registered in the period, the prospectuses were used, reports of agencies of rating or regulations, depending on the availability of information. In cases where there were not enough information to fill the database on the CVM, data were extracted from the websites of the rating agencies and fund administrators. Despite the absence of a unified database, all information is taken from official sources, in order to maintain the credibility of the study.

The funds were first divided into mono-originator, that possessed one transferor, and multi-originator, with several transferors. The multi-originator funds were excluded from the sample because the hypotheses to be tested depend on the rating of the transferor and its financial characteristics. In addition, the fund quotas that had co-obligation to the transferor were excluded because, in that way, the company would retain risks on receivables, which would disqualify it as an off-balance sheet financing.

Due to the lack of information available, it was not possible to identify whether or not the transferor companies bought part of the subordinated quotas of FIDCs. This could be classified as a form of guarantee of the transferor company, which would also prevent an offbalance sheet structuring. This study builds on securitizations prior to the implementation of resolution 3533 in 2011. Therefore, this standard does not prevented banks to characterize the sale of receivables as off-balance sheet, even when there was buying FDIC quotas by the transferor. Assuming that the sale of receivables to the funds is through a true sale, the other conditions for a structure off-balance sheet would be considered in the sample. 
Given the difficulties to obtain financial information and ratings from transferors, the basis was focused on FIDCs having banks as transferors, excluding issues for which it was not found the rating of transferors on the date of registration or that did not have the necessary information for compiling the database. Finally, the issues containing more than one series or class were separated, given the different characteristics. Because of such difficulties, the final database used in the analysis of the first hypothesis (H1) has 59 quotas issued by FIDCs from January 2005 to July 2010.

As is common in the Brazilian market, the spread of the quotas was considered as a percentage of the interest paid by the Interbank Deposit Certificate (Certificado de Depósito Interbancário - CDI). In cases where the spread was defined as a percentage over the CDI rate, the spread was converted to a percentage of CDI, using as proxy the CDI market prospects regarding the SELIC rate for the term of quotas available on the Central Bank website.

For the empirical test of the second hypothesis $(\mathrm{H} 2)$ were used banks' financial data obtained in the Central Bank's website. This analysis was also concentrated in banks due to problems in obtaining ratings and other financial information from transferor companies. All developed indicators obeyed the criteria of accounting classification published by the Central Bank. A database was prepared with 86 banks, and to each bank information for eight semesters was raised, from the second semester of 2006 to the first semester of 2010. For each semester, the considered data were from the last month of each semester, that is, June in the case of the first semester, and December in the case of the second semester. It is worth mentioning that not all banks had data available for all the semesters evaluated.

As securitized values were considered only values of mono-originator FIDCs issues registered at CVM and with the transferors banks from July 2006 to July 2010. This simplification is due to the difficulty in obtaining securitized values in the Brazilian market and it adds certain limitations to the work, since, for example, the unregistered values securitized through the issuance of FIDCs, subordinate values not issued through quotas and securitized values via multi-originator funds were not considered. To the date of securitization, it was used as a proxy the date of issue of the quotas of the FDIC.

\section{TEST METHODS}

Considering the characteristics of the databases used in the tests of the two hypotheses, both were structured as a panel. Thus, the econometric models used have been defined for this data structure. 


\subsection{FIRST HYPOTHESIS (H1): INVESTORS TAKE CREDIT RISK (RATING) OF THE TRANSFEROR INTO ACCOUNT WHEN PRICING THE FUNDS QUOTAS}

The first hypothesis (H1) to be tested was the influence of the risk of bankruptcy of the transferor in the spreads paid at the launch of the quotas of the FIDCs. As the risk of bankruptcy is not observable, the rating of the transferor company was used as a proxy. The concept behind the model used was similar to that of Gorton and Souleles (2005), using the spread of the shares as the dependent variable and the use of explanatory variables based on reinforcements of established credits and on the transferor's rating. In the Brazilian case, it was added the rating of the series, not used in the American case, because they all had the same rating (AAA), unlike in Brazil. Furthermore, despite the conceptual similarity, other variables have been replaced or adapted, given the differences between the markets and the lack of information available in the Brazilian case.

The variables related to credit enhancement, subordination, excess spread, additional guarantees and maturity were selected based on the Gorton and Souleles (2005) model and the aspects considered most relevant in securitization structures for these provide best ratings and fewer bankruptcy possibilities. Consequently, these structures should reduce the spread charged on securitisations (AYOTTE; GAON, 2005). Especially variables concerning the credit enhancement are highlighted by Fishman and Kendall (1996), Fabozzi and Roever (2003), Fabozzi and Kothari (2007) and almost all reports of the ratings agencies that analyzed FIDCs quotas. The availability of information on the basis searched was also considered in the selection of such variables. The variable defined as dependent was the spread of the quotas defined as a percentage of CDI.

The independent variables used in the model were: Mat, maturity of the quotas measured in months (as all funds included in the sample were closed, there was no amortization of quotas before maturity, except in case of early liquidation of the fund); Sub, subordination percentage of the fund; Gar, dummy to indicate additional guarantees, such as insurance or collateralization of assets (assumed the value 1 when there was some kind of additional guarantee, otherwise 0); EX Spread, dummy to indicate the presence of target for excess spread ( 1 in the case of a goal and otherwise 0 ); RT Transferor, rating of the transferor, being dummy 1 for the A ratings (AAA, AA and A) and 0 for the other ratings; RT Series, rating of the series, dummy to indicate the rating of the series that indicates the values 1 for ratings AAA and 0 for the other. Different criteria were used for the rating of the series 
and the transferor because only an issue of FDIC had lower rating than A, which would make this variable lose its significance. Equation 1 shows the basic model used.

Equation 1 - Model used in the first hypothesis (H1)

$$
\begin{gathered}
\text { Spread }_{i t}=\beta_{0}+\beta_{1} \text { Mat }_{i t}+\beta_{2} \text { Sub }_{i t}+\beta_{3} \text { Gar }_{i t}+\beta_{4} \text { Ex Spread }_{i t}+\beta_{5} \text { RT Cedente }_{i t}+ \\
\beta_{6} \text { RT Serie }_{i t}+u_{i t}
\end{gathered}
$$

All the data, including the rating of the transferor and the rating of the series, refer to the issue date of the series. Table 1 shows the detailed descriptive statistics of the used variables.

\begin{tabular}{|c|c|c|c|c|}
\hline Observations & 59 & & & \\
\hline & SPREAD & SUB & MAT & \\
\hline Mean & $113.0 \%$ & $20.5 \%$ & 43.5 & \\
\hline Median & $110.0 \%$ & $20.0 \%$ & 42.0 & \\
\hline Maximum & $159.7 \%$ & $45.0 \%$ & 96.0 & \\
\hline Minimum & $103.0 \%$ & $0.0 \%$ & 24.0 & \\
\hline Std. Dev. & $9.0 \%$ & $7.4 \%$ & 11.7 & \\
\hline \multicolumn{5}{|l|}{ Dummys } \\
\hline & Ex Spread & GAR & RT SERIE & RT CEDENTE \\
\hline $\mathrm{N}^{\circ}$ of Obs & 39 & 29 & 35 & 17 \\
\hline
\end{tabular}

Table 1 - Descriptive statistics of issues of FIDCs

Source: Elaborated by the author

The model of Gorton and Souleles (2005) used in this study was an OLS regression separating the temporal effects of the years through annual dummies and fixed effects by dummies per trust. In the Brazilian case, the use of fixed effect estimator for periods and cross section was not possible, given that the sample used, 59 quotas issued by 40 different funds, is very small.

Thus, a structured data panel model with the estimation of fixed effects for periods was used. This model aims to include in the analysis a control for specific effects of each year, which is relevant given the effects of macroeconomic fluctuations and the growth of securitization in Brazil during the analyzed period. 


\subsection{SECOND HYPOTHESIS (H2): COMPANIES WITH HIGHER CREDIT RISK SECURITIZE MORE}

To test the second hypothesis $(\mathrm{H} 2)$ the variables proposed by Gorton and Souleles (2005) were used. However, instead of the value of credit cards, the value of credit operations (OPC) was used, since the sample does not address the securitization of credit cards, but mostly, payroll loans and to purchase vehicles. The final model used as the dependent variable the securitized values on total asset ( $\mathrm{Sec} /$ Assets).

Regarding the explanatory variables, were used: Assets, the total assets of banks; OPC_Assets, credit operations (OPC) over total assets; Cap_ratio, total equity divided by total assets; A, dummy for the rating of the bank in the period, taking the value 1 for the ratings (AAA, AA, A) and 0 for all other ratings.

According to the model of Gorton and Souleles (2005), all variables, except the rating, were used in their squares and cubes as a form of control for scale effects and costs that may arise in the creation and maintenance of securitization structures. Table 2 details the descriptive statistics of the variables used. Equation 2 presents the basic model used.

Equation 2 - Model used in the second hypothesis $(\mathrm{H} 2)$

$$
\begin{gathered}
\text { Sec } / \text { Assets }_{i t}=\beta_{0}+\beta_{1} \text { Assets }_{i t}+\beta_{2} \text { Assets }^{2}{ }_{i t}+\beta_{3} \text { Assets }^{3}{ }_{i t}+\beta_{4} \text { OPC Assets }_{i t}+\beta_{5} \text { OPC Assets }^{2}{ }_{i 1} \\
\beta_{6} \text { OPC Assets }^{3}{ }_{i t}+\beta_{7} \text { Cap ratio }_{i t}+\beta_{8} \text { Cap ratio }^{2}{ }_{i t}+\beta_{9} \text { Cap ratio }^{3}{ }_{i t}+\beta_{10} \mathrm{~A}_{i t}+u_{i t}
\end{gathered}
$$

Table 2 - Descriptive statistics of variables used in $\mathrm{H} 2$

\begin{tabular}{|c|c|c|c|c|c|c|}
\hline Observations & 611 & & & & & \\
\hline & SEC/ ASSETS & ASSETS & OPC / ASSETS & CAP RATIO & $A$ & B \\
\hline Mean & $0.1 \%$ & 286.881 & $9.3 \%$ & $5.1 \%$ & & \\
\hline Median & $0.0 \%$ & 15.458 & $8.4 \%$ & $3.1 \%$ & & \\
\hline Maximum & $8.1 \%$ & 8.401 .984 & $38.5 \%$ & $79.5 \%$ & & \\
\hline Minimum & $0.0 \%$ & 184 & $0.0 \%$ & $0.1 \%$ & & \\
\hline Std, Dev. & $0.6 \%$ & 927.300 & $73 \%$ & $10.3 \%$ & & \\
\hline Total & & & & & 415 & 196 \\
\hline
\end{tabular}

Full Sample

\begin{tabular}{|c|c|c|c|c|c|c|}
\hline Observations & 135 & & & & & \\
\hline & SEC/ASSETS & ASSETS & OPC/ASSETS & CAPRATIO & $\Lambda$ & B \\
\hline Mean & $0.5 \%$ & 250.527 & $10.4 \%$ & $4.1 \%$ & & \\
\hline Median & $0.0 \%$ & 10572 & 10.25 & $3.5 \%$ & & \\
\hline Maximum & $8.1 \%$ & 8.401 .984 & 25,38 & $21.4 \%$ & & \\
\hline Minimum & $0.0 \%$ & 614 & $0.4 \%$ & $0.1 \%$ & & \\
\hline Std. Dev. & $1.1 \%$ & 1.233 .325 & $5.4 \%$ & $3.0 \%$ & & \\
\hline Total & & & & & 66 & 69 \\
\hline
\end{tabular}

Banks that securitized

Elaborated by the author 
Using the above variables, two models were tested: with estimators of fixed effects for periods and banks and fixed effect estimators only for banks. The estimators of fixed effects for banks allow to control the effects of omitted variables that vary between individuals, but are constant over time. The model assumes that there are intercepts that vary among individuals, but are constant over time. Since the same bank is used at different time periods, the use of fixed effects allows controlling any effect from the characteristics of banks that are constant over time and that could potentially hinder the analysis (MILLS; NEWBERRY, 2005).

The tested model with fixed effects estimators for banks and periods aims to add to the analysis a control for specific effects of each semester. Such effects are also cited by Gorton and Souleles (2005) in their study for the American market.

In order to separate the possible effects of major banks, were also tested two models including a interaction dummy. As in the previous cases, in this test the following models were used: the inclusion of estimators for fixed effects for banks and durations and with the addition of fixed estimators only for banks.

To avoid problems with heteroscedasticity of residuals, were considered the robust models of White in the tests for both hypotheses. As the databases used had little data by issuing or bank, no tests were performed on stationarity and autocorrelation.

\section{ANALYSIS OF RESULTS}

\subsection{HYPOTHESIS 1}

As credit enhancements have a significant influence on the rating of the securities issued in securitization structures (FISHMAN; KENDALL, 1996), were tested models including credit enhancements and not considering the rating of the series, considering the rating of the series, but not credit enhancements and considering both variables. Besides analyzing possible effects of multicollinearity, the expectation was that the inclusion of the rating of the series would reduce the representativeness of credit enhancements when analyzed together. The results are shown in Table 3. 
Table 3 - Test results for Hypothesis 1

Regression results having as dependent variable the spread of FIDC quotas. Are presented the regression coefficients (Coef) and probability ( $P$ value) of the coefficient that is not statistically different from zero Model Panel Last Squares with Fixed Effects (Periods)

\begin{tabular}{|c|c|c|c|c|c|c|}
\hline & \multicolumn{2}{|c|}{ Excluding credit enhancements } & \multicolumn{2}{|c|}{ Excluding rating of the Series } & \multicolumn{2}{|c|}{ Including credit enhancements } \\
\hline & Coef & P Value & Coef & P Value & Coef & P Value \\
\hline c & 1.18 & 0.00 & 1.18 & 0.00 & 1.23 & 0.00 \\
\hline Gar & & & 0.03 & 0.09 & 0.05 & 0.03 \\
\hline Mat & & & 0.00 & 0.42 & 0.00 & 0.48 \\
\hline Sub & & & -0.19 & 0.34 & -0.32 & 0.16 \\
\hline Ex Spread & & & -0.08 & 0.03 & -0.06 & 0.04 \\
\hline Rt Cedente & -0.04 & 0.04 & -0.06 & 0.00 & -0.05 & 0.01 \\
\hline Rt Serie & -0.06 & 0.01 & & & -0.07 & 0.01 \\
\hline Adj R Sq & 0.13 & & 0.17 & & 0.27 & \\
\hline F- Prob & 0.04 & & 0.03 & & 0.00 & \\
\hline \# Obs & 59 & & 59 & & 59 & \\
\hline
\end{tabular}

Source: Elaborated by the author

As the analysis including ratings and credit enhancements in conjunction proved to be representative, it was performed a test for multicollinearity by calculating the Variance Inflation Factor (VIF) for all variables. With all values been lower than 2, it can be said that there is no multicollinearity in the model.

According to these results, it can be noted that there are no major differences between the models. In all tests, the rating of the transferor came as a representative $(p<0.10)$ and negative coefficient, indicating that a higher rating reduces the spread charged on the issuance of the series. This result is aligned with those found by Gorton and Souleles (2005) and, through it, can be assumed that investors are concerned about the risk of the transferor companies. Therefore, it should be taken into account a possible rescue of the fund by the transferor company if it goes through financial problems and the ability of the transferor in continuing to provide quality receivables on revolving assets. This evidence contradicts the studies of Lemmon, Liu and Mao (2010).

It is noteworthy the variables of excess spread and guarantee. The first proved to be representative $(\mathrm{p}<0.10)$, with coefficients of negative sign. This result supports the theory that the credit enhancements are included in securitization structures to reduce the risk of the vehicle used in the structure. The second also proved to be representative, although with a coefficient of positive sign, contrary to expectations, since the guarantees should reduce the spread. This effect may have been caused by the fact that issues of greatest risk, besides demanding higher spreads also require the inclusion of guarantees.

It is important to note that the rating of the series was significant with a negative sign, reducing the spread, as expected. Furthermore, when the rating of the series is used in 
conjunction with other variables of credit enhancement, all continue to be representative, unlike the expected effect. One possible explanation is the other influences present in the rating of variables such as the quality of the receivables, the experience of administrators and custodians and the liquidity reserve. These were not included in the model but are present in the rating and can affect the spread.

\subsection{HYPOTHESIS 2}

Two models were tested: one including fixed effects for cross section and periods and other only for cross section. Table 4 presents detailed results of the tests.

Table 4 - Test results for Hypothesis 2

Regression results having as dependent variable the securitization value of the considered bank assets. Here are shown the regression coefficients (Coef) and probability ( $P$ value) that the coefficient is not statistically different from zero

\begin{tabular}{|c|c|c|c|c|}
\hline \multirow[t]{2}{*}{ Models } & \multicolumn{2}{|c|}{$\begin{array}{l}\text { Panel Last Squares with fixed effects } \\
\text { (periods and cross section) }\end{array}$} & \multicolumn{2}{|c|}{$\begin{array}{l}\text { Panel Last Squares fixed effects } \\
\text { (Cross Section) }\end{array}$} \\
\hline & Coef & $P$ Value & Coef & P Value \\
\hline $\mathrm{c}$ & 0.002 & 0.119 & 0.004 & 0.003 \\
\hline Assets & 0.000 & 0.360 & 0.000 & 0.365 \\
\hline Assets`2 & 0.000 & 0.535 & 0.000 & 0.427 \\
\hline Assets $^{\wedge} 3$ & 0.000 & 0.733 & 0.000 & 0.467 \\
\hline Opc_assets & 0.020 & 0.470 & -0.006 & 0.841 \\
\hline Opc_assets ${ }^{\wedge} 2$ & -0.112 & 0.524 & -0.023 & 0.893 \\
\hline Opc_assets^3 & 0.171 & 0.589 & 0.089 & 0.771 \\
\hline Cap_ratio & -0.021 & 0.422 & -0.018 & 0.513 \\
\hline Cap_ratio^2 & 0.073 & 0.370 & 0.053 & 0.523 \\
\hline Cap_ratio^3 & -0.054 & 0.399 & -0.041 & 0.516 \\
\hline $\mathrm{A}$ & -0.002 & 0.090 & -0.002 & 0.020 \\
\hline Adj R Sq & 0.088 & & 0.077 & \\
\hline F-Prob & 0.001 & & 0.002 & \\
\hline \# Obs & 611 & & 611 & \\
\hline
\end{tabular}

Source: Elaborated by the author

On the tested models, consistent with the theory approached, the rating of the bank appeared individually as significant $(\mathrm{p}<0.10)$. In both cases, the rate presented the negative sign indicating that banks with higher credit risk securitize more. This finding for the Brazilian market is in line with studies of Gorton and Souleles (2005), Mills and Newberry (2005) and Korgaonkar and Nini (2010). However, this result should be observed thoughtfully, because the coefficients associated with the rating, though representative, were close to zero.

Unlike proposed by Lemmon, Liu and Mao (2010), Korgaonkar and Nini (2010) and Gorton and Souleles (2005), no relationship between the value of assets and securitization operations were found. Nor were found the relationships indicated in Gorton and Souleles 
(2005) models, as the volume of credit transactions on the value of assets and capital ratios were not significant individually, as well as its squared and cubed values.

To remove possible effects of major banks in the analysis, was also tested a model including a interaction dummy. Such dummy was constructed using the full sample and the mean of the total assets' value of the banks. For banks that had higher active than the samples mean, the dummy had a value of 1; for banks with total assets below the mean, the dummy had the value of 0 . Also were included new dependent variables composed by multiplying the variables tested in the previous model by the described dummy.

In this case, of the 611 observations, only 96 were above the mean. This is because there is a large disparity between the larger and smaller banks, which may be seen by the large difference between the mean of total assets value of $\mathrm{R} \$ 287$ million and the median of $\mathrm{R} \$ 15.5$ million. Given this concentration, the mean was more suitable than the median for separating the effects of large banks. Again, only the rating showed to be significant $(p<10)$ in the model, including only fixed estimators for cross section. Thus, it was not possible to observe any other relationship taking by basis the model with the use of interaction dummies.

\section{FINAL CONSIDERATIONS}

This paper analyzed the Brazilian securitization market through FIDC issuances by banks, from 2005 to 2010. The tests aimed to examine empirical evidence of the existence of an implied contract between investors and transferor companies and also analyze whether riskier companies really securitize more. Given the empirical results, there are indications that the rating of the transferors affect the spreads of quotas issued through securitization, which can lead to the conclusion that there is an implicit contract between investors and transferor companies as proposed by Gorton and Souleles (2005). It was also possible to analyze the relationship between the credit rating of the analyzed banks and the ratio of securitization on the value of assets, whereas, for the analyzed period, it can be inferred that banks with worse credit ratings tend to securitize more.

In the case of the first tested hypothesis (H1), the results were quite aligned with the foreign literature. Although the securitization had as base the segregation between the risk of the transferor companies and securitized assets, ratings of the transferors shown to have influence on the spread charged on the odds of FIDCs: the worse the rating of the transferor, the greater the spreads charged by investors. As for the indicators of credit enhancement, only the excess spread and the guarantee had shown to be significant. In the first case, as expected, reducing the spread. In the case of the guarantee, it had shown with the opposite effect than 
the expected, increasing the spread. Similarly, the rating of the quotas showed a direct influence on the spread.

In the analysis of second tested hypothesis (H2), it was possible to find evidence that companies with worse ratings securitize more. This result is shown to be aligned with the literature approached and consistent with the expected benefits of securitization, as this would be more advantageous for companies with higher funding costs or worst financial indicators, factors reflected in the ratings. Unlike the international studies reviewed, there was no relationship between securitization and asset values, the amount of loans or capital ratio. This result may be related to the characteristics of securitization by banks in Brazil, which is still well linked to the sale of payroll loans and vehicle financing. Furthermore, the small number of securitization transactions by banks in the period and the used proxies also act as a limiting factor in this analysis.

Another possible explanation for the results found for the second hypothesis is the fact that companies with higher ratings have access to other forms of financing through capital markets and therefore would not have to resort to securitization. However Lemmon, Liu and Mao (2010) argue that as the SPVs issue debt in the market, companies that already have access to such markets should have more access to securitization.

Due to the lack of an organized database and the need to collect information on different bases, the unavailability of information on FIDCs in the Brazilian market appears as the major limiting factor of this study, especially in the tests of the first hypothesis (H1). Future studies may progress in this direction so that more appropriate econometric models can be used.

\section{REFERENCES}

ANBIMA. Associação Brasileira das Entidades dos Mercados Financeiro e de Capitais. Base de dados sobre FIDCs em Fundos de Investimento e Informações técnicas. 2010. Disponível em: <www.anbima.com.br> Acesso em: nov. 2010.

AYOTTE, Kenneth; GAON, Stav. Asset-backed securities: costs and benefits of bankruptcy remoteness. Texas Finance Festival, Oct. 2005. Disponível em: $<$ http://papers.ssrn.com/sol3/papers.cfm?abstract_id=813847\&rec $=1 \&$ srcabs $=561581>$. Acesso em: ago. 2010.

BCB. Banco Central do Brasil. Informações cadastrais contábeis de bancos e Focus relatório de mercado. 2010. Disponível em: 〈www.bcb.gov.br〉. Acesso em: nov. 2010.

CATÃO, Gustavo C. et al. Securitização de recebíveis no setor bancário Brasileiro: um estudo empírico. Revista Brasileira de Finanças, v. 7, n. 3, p. 327-345, maio 2009. 
CHEN, Weitzu; LIU, Chi-Chun; RYAN, Stephen G. Characteristics of securitizations that determine issuers' retention of the risks of the securitized assets. The Accounting Review, v. 83, n. 5, p. 1181-1215, apr. 2008.

CVM. Comissão de Valores Mobiliários. Regulação, dados sobre Fundos de investimentos em direitos creditórios (FIDcs) e Prospectos. 2010. Disponível em: 〈www.cvm.gov.br〉. Acesso em: nov. 2010.

FABOZZI, Frank J.; KOTHARI, Vinod. Securitization: the tool of financial transformation. Yale International Center for Finance Working Paper No. 07-07, jun. 2007. Disponível em: <http://ssrn.com/abstract=997079>. Acesso em: out. 2010.

FABOZZI, Frank J.; ROEVER, W. A. A Primer on Securitization. Journal of Structured and Project Finance, New York, v. 9, n. 2, June 2003.

FISHMAN, Michael J.; KENDALL, Leon T. A primer on securitization. Cambridge: The MIT Press, 1996. 190 p.

GELBCKE, Ernesto R.; IUDÍCIBUS, Sérgio de.; MARTINS, Eliseu. Manual de contabilidade das sociedades por ações: aplicável às demais sociedades. 7. ed. São Paulo: Atlas, 2009. $668 \mathrm{p}$.

GORTON, Gary; PENNACCHI, George. Are loan sales really off-balance sheet? Journal of Accounting, Auditing and Finance, v. 4, n. 2, p. 125-145, Spring 1989.

GORTON, Gary B.; SOULELES, Nicholas S. Special purpose vehicles and securitization. Federal Reserve Bank of Philadelphia, Working Paper No. 05-21, sep. 2005. Disponível em: <http://ssrn.com/abstract=713782>. Acesso em: out. 2010.

HIGGINS, Eric J.; MASON, Joseph. R. What is the value of recourse to asset backed securities? A clinical study of credit card banks. Federal Reserve Bank of Philadelphia Working Papers No. 03-6, 2003. Disponível em:<http://www.philadelphiafed.org/researchand-data/publications/working-papers/2003/wp03-6.pdf>. Acesso em: out. 2010.

HIGGINS, Eric J.; MASON, Joseph. R.; MORDEL, Adi. Asset sales, recourse, and investor reactions to initial securitizations: evidence why off-balance sheet accounting treatment does not remove on-balance sheet financial risk. Maio 2009. Disponível em: <http://papers.ssrn.com/sol3/papers.cfm?abstract_id=1107074>. Acesso em: out. 2010.

KARAOGLU, Emre. Regulatory capital and earnings management in banks: the case of loan sales and securitizations. FDIC Center for Financial Research, Working Paper No. 2005-05, maio 2005. Disponível em: <http://ssrn.com/abstract=722982>. Acesso em: out. 2010.

KORGAONKAR, Sanket; NINI, Greg. Special purpose vehicles and nonfinancial corporate finance. Wharton Research Scholars Program, jul. 2010. Disponível em: <http://ssrn.com/abstract=1639548>. Acesso em: out. 2010.

LELAND, Hayne E. Financial synergies and the optimal scope of the firm: implications for mergers, spinoffs, and structured finance. The Journal of Finance, v. LXII, n. 2, p. 765-802, apr. 2007. 
LEMMON, Michael L.; LIU, Laura X.; MAO, Qinghao. The use of asset-backed securitization and capital structure in industrial firms: an empirical investigation. In:

AUSTRALASIAN FINANCE AND BANKING CONFERENCE, 22., 2009. Disponível em: <http://papers.ssrn.com/sol3/papers.cfm?abstract_id=1460985>. Acesso em: out. 2010.

MYERS, Stewart. Determinants of Corporate Borrowings. Journal of Financial Economics, v. 5, n. 2, p. 147-175, nov. 1977.

MILLS, Lillian F.; NEWBERRY, Kaye J. Firms' off-balance sheet and hybrid debt financing: evidence from their book-tax reporting differences. Journal of Accounting Research, v. 43, n. 2, p. 251-282, maio 2005.

PINHEIRO, Fernando Antonio P.; SAVOIA, José. Roberto F. Securitização de recebíveis: análise dos riscos inerentes. Revista Brasileira de Finanças, v. 7, n.3, p. 305-326, 2009.

SKARABOT, Jure. Asset securitization and optimal asset structure of the firm. In: EFMA LUGANO MEETINGS, mar. 2001. Disponível em: <http://ssrn.com/abstract=263088>. Acesso em: out. 2010.

THOMAS, Hugh.; WANG, Zhiqiang. A cost of capital analysis of the gains from securitization. In: BERGMANN, Matthaus; FAUST, Timotheus (Ed.). Handbook of business and finance: multinational companies, venture capital and non-profit organizations. Nova Science Publishers Inc, 2009. cap. 6, p. 147-170. 